\title{
Clavanin bacterial sepsis control using a novel methacrylate nanocarrier
}

\author{
This article was published in the following Dove Press journal: \\ International Journal of Nanomedicine \\ 31 October 2014 \\ Number of times this article has been viewed
}

\section{Amanda CM Saúde \\ Alicia S Ombredane' \\ Osmar N Silva' \\ João ARG Barbosa ${ }^{1,2}$ \\ Susana E Moreno ${ }^{3}$ \\ Ana Claudia Guerra \\ Araujo ${ }^{4}$ \\ Rosana Falcão 4 \\ Luciano P Silva ${ }^{4}$ \\ Simoni C Dias' \\ Octávio L Franco',3}

'Programa de Pós Graduação em Ciências Genômicas e Biotecnologia, Centro de Análises Proteômicas e Bioquímicas, Universidade Católica de Brasília, Brasília, FD, Brazil; 'Laboratório de BiofísicaDepartamento de Biologia Celular-IB, Universidade de Brasília - UNB, DF, Brazil; ${ }^{3}$ Universidade Católica Dom Bosco - UCDB, Campo Grande, MS, Brazil; ${ }^{4}$ Empresa Brasileira de Pesquisa Agropecuária - EMBRAPA - Recursos Genéticos e Biotecnologia, Brasília, DF, Brazil
Correspondence: Octávio L Franco Universidade Catolica de Brasilia, SGAN 916 Módulo B Avenida W5, 70790- 160 Brasília/DF, Brazil $\mathrm{Tel}+556 \mid 3448$ 7l34 Email ocfranco@gmail.com
Abstract: Controlling human pathogenic bacteria is a worldwide problem due to increasing bacterial resistance. This has prompted a number of studies investigating peptides isolated from marine animals as a possible alternative for control of human pathogen infections. Clavanins are antimicrobial peptides isolated from the marine tunicate Styela clava, showing 23 amino acid residues in length, cationic properties, and also high bactericidal activity. In spite of clear benefits from the use of peptides, currently $95 \%$ of peptide properties have limited pharmaceutical applicability, such as low solubility and short half-life in the circulatory system. Here, nanobiotechnology was used to encapsulate clavanin A in order to develop nanoantibiotics against bacterial sepsis. Clavanin was nanostructured using EUDRAGIT ${ }^{\circledR}$ L 100-55 and RS $30 \mathrm{D}$ solution $(3: 1 \mathrm{w}: \mathrm{w})$. Atomic force, scanning electron microscopy and dynamic light scattering showed nanoparticles ranging from 120 to $372 \mathrm{~nm}$ in diameter, with a zeta potential of $-7.16 \mathrm{mV}$ and a polydispersity index of 0.123 . Encapsulation rate of $98 \%$ was assessed by reversed-phase chromatography. In vitro bioassays showed that the nanostructured clavanin was partially able to control development of Staphylococcus aureus, Klebsiella pneumoniae, and Pseudomonas aeruginosa. Furthermore, nanostructures did not show hemolytic activity. In vivo sepsis bioassays were performed using C57BL6 mice strain inoculated with a polymicrobial suspension. Assays led to $100 \%$ survival rate under sub-lethal sepsis assays and $40 \%$ under lethal sepsis assays in the presence of nanoformulated clavanin A until the seventh day of the experiment. Data here reported indicated that nanostructured clavanin A form shows improved antimicrobial activity and has the potential to be used to treat polymicrobial infections.

Keywords: peptides, antimicrobial, nanoparticles, nanobiotechnology

\section{Introduction}

The infections associated with human health have led to an increase in pharmacy and hospitalization costs and also to a rise in mortality rates. ${ }^{1}$ Many bacterial lineages can be isolated from nosocomial infections, including the Gram-positive bacteria Staphylococcus aureus and S. epidermidis as well as the Gram-negative bacteria Escherichia coli, Pseudomonas spp., Klebsiella spp., Proteus spp., Enterobacter spp., and Serratia spp. ${ }^{2}$ Sepsis infections are increasingly common among intensive care unit (ICU) patients. ${ }^{3}$ Worldwide, it has been estimated that $30.8 \%$ of these sepsis cases could lead to death, whilst in Latin America around 25\% of hospital beds are occupied by sepsis patients, with $57.3 \%$ of cases leading to death. ${ }^{4}$

Therefore, many studies have joined the search for innovative antibiotic molecules, which include antimicrobial peptides. These compounds display different defense mechanisms, including membrane disruption, which plays a critical role against pathogenic microorganisms. Clavanin is an antimicrobial peptide family composed of four isoforms ("A," "B," “C," and "D”) isolated from Styela clava hemocytes. 
Clavanins were first described by Lee et $\mathrm{al}^{5}$ who showed that clavanins were effective against infections by fungi and Gram-positive (including multi-resistant S. aureus, [MRSA]) and Gram-negative bacteria. Clavanins have 23 amino acid residues in length and are rich in histidine, glycine, and phenylalanine amino acid residues, presenting an amidated C-terminal. ${ }^{5}$ Furthermore, some clavanin peptides not only display antimicrobial activity but also an immunomodulatory activity, which is characterized by host innate humoral immune response against pathogenic microorganisms. ${ }^{6}$ In sepsis cases, immunomodulatory peptides may selectively suppress pro-inflammatory responses and increase the protective effect of immune activity. ${ }^{6}$

In spite of clear benefits from the use of bioactive peptides, currently $95 \%$ of peptide properties have limited pharmaceutical applicability due to some characteristics such as short half-life in the circulatory system, toxicity, uncontrolled release, immunogenicity, and costs for therapies. $^{7-9}$ Another significant problem to be solved consists of biodistribution. Proteins and peptides are strongly affected by rapid hydrolysis by proteases in the blood stream and low permeability across biological barriers. ${ }^{10}$ Furthermore, biodistribution can also be influenced by different factors such as physicochemical properties, size, shape, and route of administration. ${ }^{11}$ In this context, injectable nanoparticles can be driven to different tissues, since they are directly affected by blood vessel endothelium. For example, lungs and muscles only allow entrance of molecules of less than $3 \mathrm{~nm}$, which can be transported across the capillary wall. However, the kidneys, liver, and spleen have blood vessels with larger pore spaces, allowing the entrance of molecules up to $60 \mathrm{~nm}$ (hydrodynamic diameter). ${ }^{11}$

In this regard, some studies have developed strategies to protect peptides and proteins against in vivo systems. Among them, nanostructures have been considered as efficient carriers since they provide higher levels of biodegradability and biocompatibility. Recent studies showed nanometric systems developed to deliver different compounds involved in the treatment of pathologies, among them chemotherapeutic molecules, bronchodilators, and antibiotics. ${ }^{12-16}$

Different nanosystems can be used to prepare drug carriers, including polymeric nanoparticles that consist of colloidal carrier systems of up to $1,000 \mathrm{~nm}$ in diameter. ${ }^{16}$ In order to obtain higher antibiotic therapeutic efficacy and avoid the microorganisms' resistance mechanisms, polymeric systems for drug carriers can be rationally designed. Focus should be given to peptide protection from the host system, increasing bacterial membrane specificity and controlled release to decrease peptide concentrations and number of doses needed. ${ }^{12,15}$ Although nanoparticles containing conventional antibiotics have been described, few studies have reported nanoparticles containing antimicrobial peptides. In the present study, two methacrylate-based polymers, EUDRAGIT ${ }^{\circledR} \mathrm{L}$ 100-55 and RS 30 D, were used. EUDRAGIT ${ }^{\circledR}$ L 100-55 is formed by an anionic copolymer based on methacrylic acid and ethyl acrylate. Furthermore, EUDRAGIT ${ }^{\circledR}$ RS 30 D is a copolymer formed by ethyl acrylate, methyl methacrylate, and low content of methacrylic acid ester with quaternary ammonium groups. ${ }^{17}$ The ammonium groups are present as salts and make the polymers permeable. ${ }^{17}$ These polymers have been used for pharmaceutical purposes as previously described. ${ }^{17,18}$ These polymers present $99 \%$ purity, ${ }^{17,19}$ simplifying the nanostructuration protocol based on hydrophobicity and higher encapsulation efficiency. ${ }^{10,17,19-22}$ Polymer hydrophobicity allows its solubilization on acetone $95 \%$ and ethanol 5\% solution, and further peptide coupling occurs after water addition, due to amphipathic properties of clavanin used here. Moreover, release assays showed a higher stability of methacrylate nanostructures in water, as discussed above. This assay provides information about storage stability, since the nanostructures were only applied to water environment. ${ }^{23}$

Bi et $\mathrm{al}^{24}$ developed phytoglycogen-based nanoparticles containing the antimicrobial peptide nisin, effective against Listeria monocytogenes. Furthermore, Liu et $\mathrm{al}^{25}$ showed core-shell nanostructured nanoparticles formed from TAT sequence (YGRKKRRQRRR) against $S$. aureus. ${ }^{25}$ Here, methacrylate polymers (EUDRAGIT ${ }^{\circledR}$ L 100-55 and RS $30 \mathrm{D})$ were used to encapsulate the antimicrobial and immunomodulatory peptide clavanin A, and their activity was further evaluated in vitro and in vivo using septicemic models. Morphological analysis of encapsulated clavanin A indicates particle integrity, stability, and diameter regularity, as well as its in vitro and in vivo efficiency. Current analysis demonstrates the potential activity of this novel compound combination against polymicrobial infection.

Here, a novel antibiotic is examined, for potential use against polymicrobial infections that can progress to sepsis infections, commonly observed among ICU patients, leading to higher mortality rates and ever-increasing hospitalization costs. Current antibiotics do not show efficient activity against some bacterial species, and a real need for novel antibiotic development is necessary. The use of nanotechnology associated with antimicrobial peptides as a new tool for antibiotic development is proposed. Moreover, polymeric EUDRAGIT ${ }^{\circledR}$ nanoparticles with $\mathrm{pH}$ dependence and 
biodegradability were used in order to improve clavanin A stability in the host system.

\section{Material and methods}

\section{Synthesis and peptide purity evaluation}

Clavanin A (VFQFLGKIIHHVGNFVHGFSHVF- $\mathrm{NH}_{2}$ ) was synthesized by China Peptides Co., Ltd., using solid phase method and F-moc strategies. ${ }^{26}$ Lyophilized peptide was re-suspended in $0.1 \%$ TFA (trifluoroacetic acid) and further purified using a reverse-phase analytical HPLC (high-performance liquid chromatography) Phenomenex $\mathrm{C}_{18}$ column $(4.6 \mathrm{~mm} \times 250 \mathrm{~mm})$, with a linear acetonitrile gradient $(5 \%-95 \%)$ at a flow rate of $1.0 \mathrm{~mL} \cdot \mathrm{min}^{-1}$. Peptide elution was monitored at 216 and $280 \mathrm{~nm}$ absorbance. Molecular mass and purity of synthetic peptide was confirmed by MALDI-TOF/TOFTM UltraFlex III (Bruker Daltonics, Billerica, MA, USA) analyses. Samples were solubilized in $\alpha$-cyano-4-hydroxycinnamic acid saturated solution (1:3), and $1 \mu \mathrm{L}$ of this solution was applied onto MALDI plate type MTP 384 and further air-dried. Mass spectrometer was calibrated with Peptide Calibration Standard II (Bruker Daltonics). Theoretical monoisotopic mass value was obtained by Protein Prospector (http://prospector.ucsf.edu/prospector/ mshome.htm) and was compared with experimental values obtained. For peptide quantification, absorbance measurements at three different wavelengths $(205,215$, and $225 \mathrm{~nm})$ were performed according to Murphy and Kies. ${ }^{27}$

\section{Polymeric nanoparticle preparation}

Nanostructures were prepared by using $100 \mu \mathrm{g}$ of synthetic clavanin A (in the presence of polymer (EUDRAGIT ${ }^{\circledR} \mathrm{L}$ 100-55) and copolymer (EUDRAGIT ${ }^{\circledR}$ RS 30 D) at different ratios $(1: 3,1: 1$, and $3: 1 \mathrm{~m}: \mathrm{m})$. According to sample analysis by atomic force microscopy (AFM), described in the next topic, it was determined that only the $3: 1$ ratio $(22.5 \mathrm{mg}$ of polymer and $7.5 \mathrm{mg}$ of copolymer) could lead to nanoparticle formation. For this reason, this proportion was maintained in all experiments described. ${ }^{28}$ Nanoparticles were prepared from oil/water emulsion by using $95 \%$ acetone and $5 \%$ ethanol solution at 1:10 ratio (mass of polymer and copolymer for acetone and ethanol solution). Labrafil ${ }^{\circledR}$ M1944CS was used as a surfactant at concentration of $1.14 \mathrm{mg} \cdot \mathrm{mL}^{-1}$. Aiming to improve solubilization, reagents were added to main solution following the sequence EUDRAGIT ${ }^{\circledR}$ RS $30 \mathrm{D}$, EUDRAGIT $^{\circledR}$ L 100-55 D, surfactant, and peptide. Further, $2.25 \mathrm{~mL}$ of autoclaved ultrapure water was added, aiming to induce nanoparticle aggregation by hydrophobicity. ${ }^{18}$ This solution was incubated at $4^{\circ} \mathrm{C}$ for 12 hours and centrifuged at $13,400 \times g$ for 30 minutes at room temperature to remove residues. Then, the supernatant was collected, and the precipitate discarded. To remove the organic solvents a rotaevaporation system in $\mathrm{Buchi}^{\circledR}$ RIII equipment was used at constant pressure (20 in. $\mathrm{Hg}$ ), for 10 minutes at $37^{\circ} \mathrm{C}$ and once more centrifuged at $13,400 \times g$ for 30 minutes at room temperature in order to remove any residues.

\section{Morphological analysis}

Aiming to observe a complete morphological analysis, three different methods were used for better understanding nanostructure behavior, including AFM, scanning electron microscopy (SEM), and dynamic light scattering (DLS). ${ }^{29,30}$

\section{Atomic force microscopy}

Nanoparticle diameter (nm) was determined by AFM using SPM 9600 equipment (Shimadzu Corporation, Kyoto, Japan). Aiming to obtain suitable concentration, samples were diluted at 1:100 ( $\mu \mathrm{L})$ sample/ultrapure water ratio, with $1 \mu \mathrm{L}$ of diluted sample applied onto freshly cleaved mica-muscovite surface and fixed to metallic sample support. Images were obtained in dynamic mode, using a probe (PPP-NCHR NanoSensors ${ }^{\circledR}$ ). ${ }^{31}$ After drying the samples, images with 512 pixels $\times 512$ pixels of resolution, maximum dimension of $125 \mu \mathrm{m} \times 125 \mu \mathrm{m}$, and scan areas of $50 \mu \mathrm{m} \times$ $50 \mu \mathrm{m}$ and $10 \mu \mathrm{m} \times 10 \mu \mathrm{m}$ were obtained. SPM-9600 off-line software was used in order to adjust the image plane. Particle analysis was performed using the same software.

\section{Scanning electron microscopy}

For morphological analysis of particles by SEM, a Zeiss DSM 962 (Carl Zeiss Meditec AG, Jena, Germany) microscope was used. Nanoparticles were applied to a clean coverslip and partially dehydrated at $37^{\circ} \mathrm{C}$ for 5 days. After this, pieces of the coverslip were affixed to the stubs surface using doublesided adhesive conductive carbon tape. Stubs were recovered with a gold ultra-thin layer $(20 \mathrm{~nm})$ using the Sputter Coat Emitech K550. SEM images were analyzed and captured, and particle shape and size were determined.

\section{Dynamic light scattering}

The hydrodynamic diameters of the nanostructures were evaluated using a Zetasizer nano ZS ZEN3600 (Malvern Instruments, Malvern, UK) DLS instrument equipped with a $633 \mathrm{~nm}$ (red) He-Ne $4 \mathrm{~mW}$ laser. Polyethylene disposable cells were used for this analysis. The nanoparticle solution was centrifuged at $13,400 \times g$ prior to measurement in order 
to eliminate possible high molecular weight contaminants present in the sample solution. The precipitate was discarded, and the supernatant was used for analysis. A total of three readings were performed using $1 \mathrm{~mL}$ of nanoparticle sample containing $100 \mu \mathrm{g} \cdot \mathrm{mL}^{-1}$ nanostructured clavanin at $25^{\circ} \mathrm{C}$. Each reading was composed of 15 measurements of the backscattering $\left(173^{\circ}\right)$ intensity collected for 70 seconds by an Avalanche photodiode detector. Zetasizer software version 6.11 was used for data processing and analysis.

\section{Encapsulation efficiency}

Encapsulation efficiency was estimated for the total clavanin A coupled to fluorescein isothiocyanate (Clav-FITC) applied from the nanostructuration process. Before peptide encapsulation, the fluorophore FITC was coupled to clavanin A at a 1:2 ratio, respectively. After peptide marking, Clav-FITC was applied onto a $1 \mathrm{kDa}$ pore-size minidialysis tube for 12 hours at $4^{\circ} \mathrm{C}$, aiming to remove free FITC. A standard curve using FITC coupled to peptide was performed to quantify the free peptide after nanostructure release (data not shown). Free Clav-FITC was analyzed using spectrofluorimeter (FP 6500; JASCO, Tokyo, Japan) coupled to a Peltier temperature control system (JASCO).

\section{In vitro peptide release assays}

For in vitro peptide release assays, samples were divided into $1 \mathrm{~mL}$ aliquots containing $100 \mu \mathrm{g} \cdot \mathrm{mL}^{-1}$ of nanostructured clavanin solubilized in water, being further incubated at $37^{\circ} \mathrm{C}$. Clav-FITC was applied from the nanostructuration process and then collected at intervals of 24 hours during a 7-day period. In order to separate released Clav-FITC from other compounds and residues, all samples were applied in Amicon $^{\circledR} 10 \mathrm{kDa}$ ultrafilter and centrifuged at $4,400 \times g$ for 10 minutes. Supernatant was discarded and the precipitate collected and further analyzed in a spectrofluorimeter (FP 6500; JASCO) coupled to a Peltier temperature control system (JASCO).

\section{In vitro antibacterial assays}

Antibacterial in vitro assays were performed against Gram-positive (S. aureus ATCC25923) and Gram-negative (E. coli ATCC8739, K. pneumoneae ATCC13885, and P. aeruginosa ATCC 27853) bacteria. Aiming to obtain pure colonies, bacteria were previously plated and incubated for 48 hours at $37^{\circ} \mathrm{C}$. A single colony was isolated to be replicated in Luria Bertani medium $(5 \mathrm{~mL})$ and incubated for 12 hours at $37^{\circ} \mathrm{C}$ and $240 \mathrm{rpm}$. In order to analyze in vitro antimicrobial activities, different samples were assayed, including nanoparticles without peptide and free clavanin, and nanoparticles containing clavanin at a standard concentration of $12 \mu \mathrm{g} \cdot \mathrm{mL}^{-1}$. Chloramphenicol was used as a positive control. Distilled water was used as negative control. In vitro antibacterial activity was evaluated by the analysis of the absorbance measurement at $595 \mathrm{~nm}$, every 30 minutes, for 12 hours. All assays were performed in enzyme-linked immunosorbent assay (ELISA) microplates with 96 wells, with $100 \mu \mathrm{L}$ final volume in each well, and assays were performed in triplicate. ${ }^{32}$

\section{In vivo antibacterial activities}

This study was approved by the Animal Use Committee (CEUA) at the Institute of Biological Sciences, number 0177-07, University of Brasilia. In vivo sepsis analysis was performed according to the method proposed by Moreno et $\mathrm{al}^{33}$ involving intraperitoneal sepsis induction in mice using an injection containing a bacteria pool. For in vivo experiments, C57BL/6 mice were obtained from the Universidade Católica Dom Bosco, housed in temperature-controlled cages $\left(22^{\circ} \mathrm{C}-24^{\circ} \mathrm{C}\right)$, and received food and water ad libitum. Bacteria were previously obtained from mice cecum and further filtered, plated in $\mathrm{BHI}$ (brain-heart infusion) medium and incubated at $37^{\circ} \mathrm{C}$ for 21 hours. Bacterial suspension was centrifuged, and precipitate was collected and solubilized in sterile saline solution. After this, $60 \%$ glycerol was added to this suspension, which was stored at $-80^{\circ} \mathrm{C}$. In order to prepare the suspensions for in vivo assays, one of the aliquots was incubated at $37^{\circ} \mathrm{C}$ for 21 hours. Further suspensions were serially diluted $(1: 2)$ and then quantified by spectrophotometer at $595 \mathrm{~nm}$ absorbance. Bacterial suspension (P. aeruginosa, S. aureus, E. coli, and K. pneumoniae) was identified using three different methods: TSI (triple sugar iron)-containing agar, SIM (sulfide indole motility), and citrate test. ${ }^{34}$ Bacterial suspensions were quantified with $4.1 \times 10^{10} \mathrm{CFU} \cdot \mathrm{mL}^{-1}$ concentrations. Next, sepsis severity groups were defined according to the amount of suspension applied on each mouse. In the lethal group (L), $25 \mu \mathrm{L}$ of $1.02 \times 10^{9} \mathrm{CFU}$ bacterial suspension was applied per mouse, and in the sub-lethal group (SL) $15 \mu \mathrm{L}$ of $6.15 \times 10^{8} \mathrm{CFU}$ bacterial suspension was applied per mouse. The lethal group was considered to present $90 \%-100 \%$ of mortality, and the sub-lethal group presented $40 \%-60 \%$ of survival. The L experimental group was divided, thus, into six groups with five animals in each, and the SL experimental group was divided into four subgroups with five animals in each. Treatment groups were divided into infected and untreated, 
infected and treated with nanostructured clavanin A $\left(2 \mu \mathrm{g} \cdot \mathrm{mL}^{-1}\right)$, infected and treated with nanostructured clava$\operatorname{nin} \mathrm{A}\left(4 \mu \mathrm{g} \cdot \mathrm{mL}^{-1}\right)$, infected and treated with nanostructured clavanin A $\left(12 \mu \mathrm{g} \cdot \mathrm{mL}^{-1}\right)$, infected and treated with empty nanostructures, and infected and treated with free clava$\operatorname{nin}\left(12 \mu \mathrm{g} \cdot \mathrm{mL}^{-1}\right)$. The animals were pretreated according to treatment groups. After 15 minutes, the animals were infected with bacterial suspension. Then the animals were treated according to group, and every 24 hours, each animal received the specific treatment established for the group. Aiming to estimate the survival function of lifetime data obtained from the survival experiment (lethal and sub-lethal doses), Kaplan-Meier estimator methodology was used. ${ }^{35}$

\section{In vitro immunomodulatory assays}

Immunomodulatory assays were performed by using RAW 264.7 murine macrophage-like cells. RAW 264.7 cells were obtained from the Cell Bank of Rio de Janeiro (CR108) and maintained in supplemented DMEM medium (Gibco ${ }^{\circledR}$; Thermo Fisher Scientific, Waltham, MA, USA) containing $10 \%$ of fetal bovine serum, $100 \mathrm{U} \cdot \mathrm{mL}^{-1}$ penicillin and $100 \mathrm{U} \cdot \mathrm{mL}^{-1}$ streptomycin; these cells were then incubated in the presence of $\mathrm{CO}_{2}$ at $37^{\circ} \mathrm{C}$. Cytokine production (tumor necrosis factor [TNF]- $\alpha$, interleukin [IL]-10, and IL-12) was evaluated on RAW 264.7 cell culture supernatant. After incubation, cells were stimulated with $S$. aureus and $E$. coli $\left(5 \times 10^{5} \mathrm{CFU} \cdot \mathrm{mL}^{-1}\right)$ antigen, with and without recombinant interferon (IFN)- $\gamma\left(10 \mathrm{ng} \cdot \mathrm{mL}^{-1}\right)$ (PeproTech, Rocky Hill, NJ, USA). After this, aiming to observe a major cytokine action (inflammatory TNF- $\alpha$, IL-12, and regulatory IL-10), microplates were incubated for 24 hours (TNF- $\alpha$ and IL-12) and 72 hours (IL-10) at $37^{\circ} \mathrm{C}$, with $5 \% \mathrm{CO}_{2}$. TNF- $\alpha$, IL-10, and IL-12 supernatant concentrations were determined by ELISA, according to the manufacturer's specifications (PeproTech). Cytokine levels were expressed in picograms per milliliter $\left(\mathrm{pg} \cdot \mathrm{mL}^{-1}\right){ }^{36}$

\section{Results and discussion Morphological characterization of nanoparticles}

To prepare methacrylate nanoparticles containing the antimicrobial peptide clavanin A, three different ratios of polymers EUDRAGIT $^{\circledR}$ L 100-55 and EUDRAGIT ${ }^{\circledR}$ RS 30 D were used: $1: 3,1: 1$, and $3: 1$. These polymeric nanoparticles consist of a colloidal system, which aims to protect molecules or biomolecules, in this case, against the host's immune system and proteinases. ${ }^{12}$ Figure $\mathrm{S} 1$ shows a simple scheme for data presentation.
EUDRAGIT ${ }^{\circledR}$ L 100-55 is an anionic copolymer based on methacrylic acid and ethyl acrylate. This polymer contains free carboxyl groups coupled to ester groups. EUDRAGIT ${ }^{\circledR}$ RS 30 D contains ethyl acrylate, methyl methacrylate, and methacrylic acid (low concentration). These compounds were used to obtain an insoluble polymer with no $\mathrm{pH}$ dependence. RS 30 D polymer has a quaternary ammonium group in its structure, which increases polymer permeability. Using these two polymers (EUDRAGIT ${ }^{\circledR}$ L 100-55 and RS 30 D) at different concentrations, viable nanostructures for drug delivery were obtained. ${ }^{17,19-21}$ These polymers have been widely used for drug carrier development, since they show $\mathrm{pH}$ dependence, biocompatibility, stability, and polyelectrolysis characteristics, which are convenient for gastric or intestinal administration. ${ }^{37}$

Using methacrylate polymer, some studies have shown the viability of EUDRAGIT ${ }^{\circledR}$ polymer to encapsulate different drugs. Moustafine et $\mathrm{al}^{37}$ showed the use of EUDRAGIT ${ }^{\circledR}$ L 100-55 on interpolyelectrolyte complexes, demonstrating high structural stability and viability for drug-delivery applications, since it showed $\mathrm{pH}$ dependence, which led to differential drug release at different $\mathrm{pHs}$, and also biocompatibility. Cetin et $\mathrm{al}^{20}$ showed diclofenac sodium encapsulation with EUDRAGIT $^{\circledR}$ L 100 and EUDRAGIT ${ }^{\circledR}$ L 100-poly(lacticco-glycolic acid) (PLGA) nanoparticles, and the production of nanostructures ranging from 241 to $274 \mathrm{~nm}$ in diameter. ${ }^{20}$ Another study carried out by Yoo et $\mathrm{al}^{21}$ showed the efficacy of EUDRAGIT ${ }^{\circledR}$ S 100 nanoparticles. For this, the authors encapsulated a model compound (sodium fluorescein or Nile red) for vaginal-specific drug-delivery system, and showed nanoparticles of 211-331 nm to be potential carriers in topical and systemic delivery. ${ }^{21}$

The use of polymeric nanostructures to encapsulate different drugs has been extensively studied. Cheow et a ${ }^{38}$ produced encapsulated levofloxacin in polymeric nanoparticles, of poly( $\varepsilon$-caprolactone) and PLGA polymers. Nanostructures were 80 and $230 \mathrm{~nm}$ in diameter, by DLS. ${ }^{22}$ Moreover, Fontana et $\mathrm{al}^{39}$ presented an interesting study using amoxicillinloaded polyethylcyanoacrylate nanoparticles with added polyethyleneglycol (PEG), measuring 220-320 nm. Turos et $\mathrm{al}^{14}$ proposed penicillin-bonded polyacrylate nanoparticles with $25-40 \mathrm{~nm}^{.14}$

The nanoparticles produced in the present study were characterized by AFM, SEM, and DLS. AFM analysis for the 1:3 polymer ratios did not show structured nanoparticles (data not shown). For the 1:1 ratio, no image was obtained due to a probable ferrule contamination, in the sample or from sample residues attached to the tip-cantilever. ${ }^{40}$ Image 
analysis obtained in the 3:1 ratio showed nanoparticles with a dry diameter by height of $120 \mathrm{~nm}$ (Figure 1A and B) with a bimodal Gaussian distribution between 69 and $260 \mathrm{~nm}$ (Figure S2). In order to confirm the nanoparticle size (at 3:1 ratio), SEM analyses were also performed and showed particles with uniform shapes (Figure 1C and D). In addition, DLS analyses were performed showing nanoparticles with approximately $372 \mathrm{~nm}$ in hydrodynamic diameter and a unimodal Gaussian distribution (Figure S3A).

There is a significant difference in the measured ranges for the nanoparticle sizes between the methodologies using dried (AFM and SEM) and suspended (DLS) samples. Size divergence can be explained by conditions for DLS and SEM/AFM analyses; in summary, AFM and SEM analyses used dried samples, and under these conditions a significant decrease in diameter size could be observed. ${ }^{30}$ DLS analyses showed nanoparticle behavior in solution, complementing morphological analysis of methacrylated nanoparticles. ${ }^{41}$ In this context, Chicea ${ }^{29}$ compared two biological samples (human serum albumin and red blood cells) using DLS and
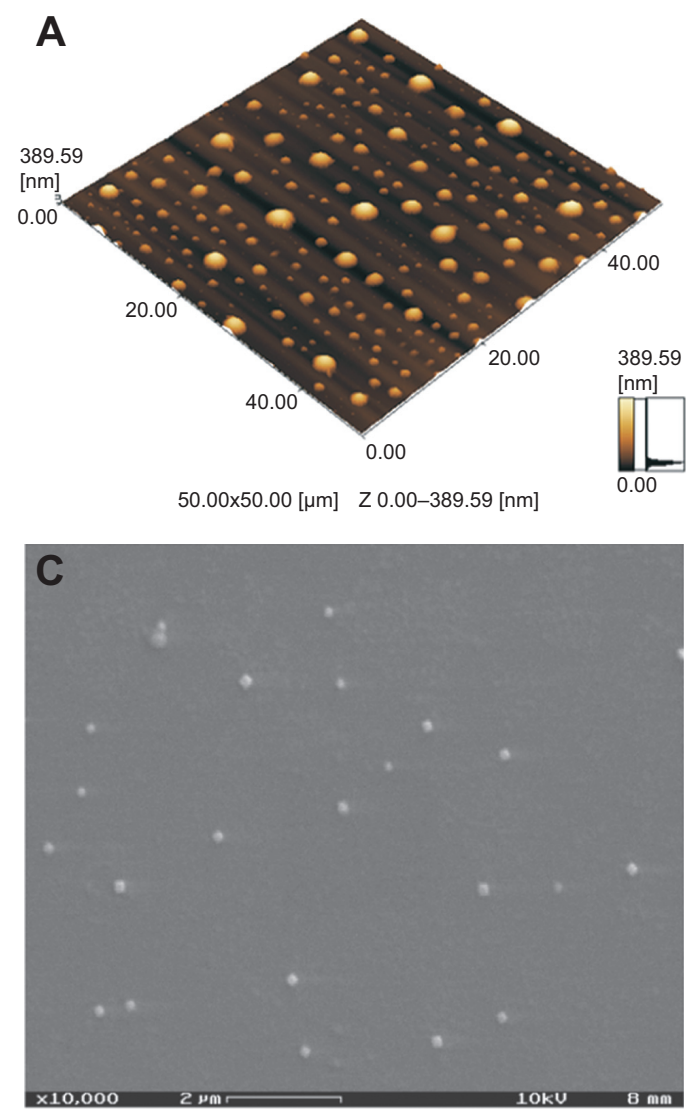

AFM methodologies, showing different results, with the smallest size being always observed with AFM analysis. Turos et $\mathrm{al}^{14}$ demonstrated the importance of DLS and AFM for nanoparticle characterization by using polyacrylate nanoparticles containing penicillin.

Another interesting property related to nanoantibiotic development is the polydispersity index (PDI). Indeed, previous studies showed nanoformulations with PDI in the range of 0.01-0.50 indicating low aggregation probability, while samples with 0.70 or higher PDI indicated a high aggregation probability correlated to a wide variation in nanoparticle size. ${ }^{42}$ In this work, a PDI of 0.123 was obtained from the DLS measurements, using methacrylate nanoparticles with 3:1 EUDRAGIT ${ }^{\circledR}$ L 100-55 and RS 30 D. In the case reported here, there is no aggregation probability according to nanoparticle PDI.

This was corroborated by microscopic analyses (Figure 1A-D). Nidhin et $\mathrm{al}^{43}$ showed the difference in PDI using different polymers and methodologies. These authors showed that nanoparticles produced using alginate
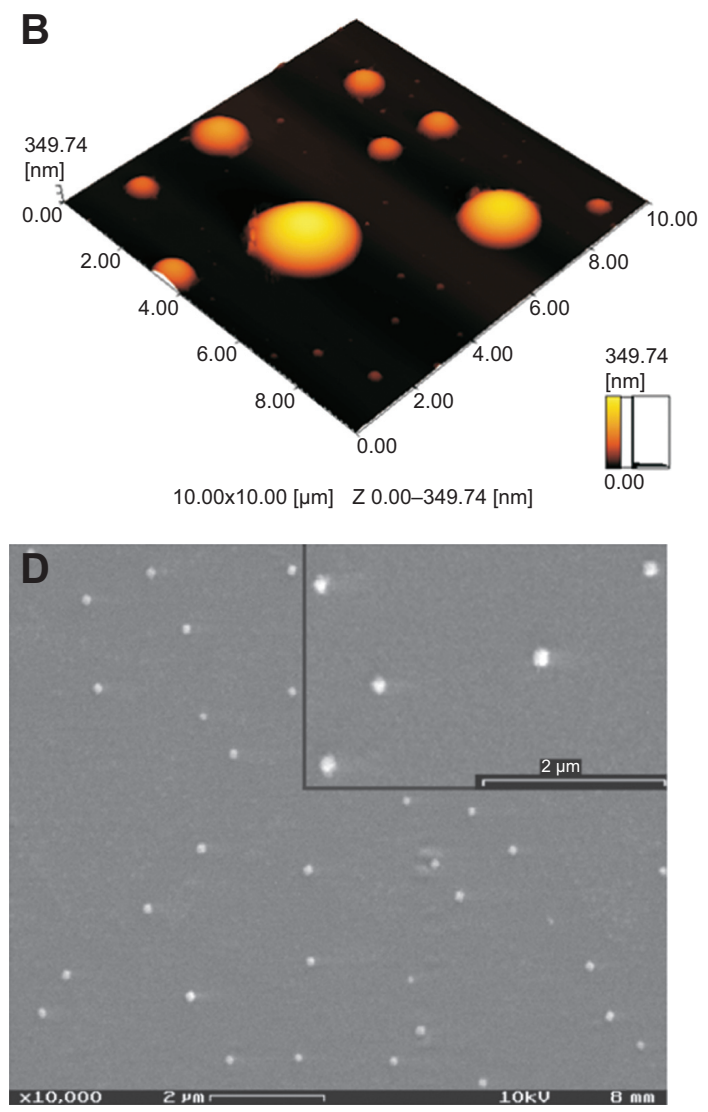

Figure I Polymeric nanoparticles were obtained by using polymer and copolymer at 3:I (w:w) rates, with I00 $\mu \mathrm{g}$ synthetic clavanin A.

Notes: Aiming to observe these structures, AFM and SEM were used. AFM images were obtained by SPM 9600 (Shimadzu Corporation, Kyoto, Japan) equipment (A and B) using muscovite mica surface. The images were adjusted in the $X$ and $Y$ plane, and poor training removed from lines. Scanning area of $50 \mu \mathrm{m} \times 50 \mu \mathrm{m}(\mathbf{A})$ and $10 \mu \mathrm{m} \times 10 \mu \mathrm{m}$ (B). SEM images (C and D) show the integrity of the nanoparticles containing the peptide clavanin A after partial dehydration for 5 days at $30^{\circ} \mathrm{C}$.

Abbreviations: AFM, atomic force microscopy; SEM, scanning electron microscopy. 
presented 0.31-0.55 PDI, while with chitosan, nanoparticles of 0.11-0.48 PDI were observed, and for starch nanoparticles the observed PDI was in the range of $0.11-0.27 .{ }^{43}$ Fontana et $\mathrm{al}^{39}$ showed amoxicillin nanoparticles associated with PEG. In this case, nanoparticles showed PDI of 0.28-0.60, depending on PEG concentration. ${ }^{39}$ In two other studies using EUDRAGIT ${ }^{\circledR}$ nanoparticles, Yoo et $\mathrm{a}^{21}$ presented 0.23 PDI, while Cetin et $\mathrm{al}^{20}$ showed PDI of 0.12-0.19, depending on nanoparticle size and PLGA to EUDRAGIT ${ }^{\circledR}$ ratios. Therefore, methacrylate nanoparticles shown here present promising PDI values for injectable antibiotic development, since they present stability and no aggregation probability according to the nanoparticle PDI.

The zeta potential experiment showed nanoparticles with $-7.16 \mathrm{mV}$ (Figure S3B). According to the American Society for Testing and Materials, zeta potentials above \pm 30 show a higher colloidal stability. In this work, nanostructured clavanin showed a lower zeta potential, $-7.16 \mathrm{mV}$, but this characteristic allowed an anionic charge, lower agglomerate formation, and viable PDI values for injectable antibiotic development. ${ }^{44}$ On the other hand, surface charge can affect the immune system response against nanoparticles, and positive nanoparticles charge showed a higher immune response when compared with negative or neutral nanoparticles. However, the optimal charge for nanoparticles has been described between +10 and $-10 \mathrm{mV}$, since these charges provide lower phagocytosis and probably minimize nonspecific interaction between nanoparticles, increasing biocompatibility. ${ }^{45}$ In this context, Nidhin et $\mathrm{al}^{43}$ showed a different zeta potential for nanoparticles produced with different polymers. By using alginate, the authors found a zeta potential between -11.9 and $-4 \mathrm{mV}$, while for chitosan nanoparticles, potentials of -14 to $1.3 \mathrm{mV}$ were observed, and for starch nanoparticles, the value was $13 \mathrm{mV} \cdot{ }^{43}$ EUDRAGIT $^{\circledR}$ nanoparticles, observed by Cetin et $\mathrm{a}^{20}$ demonstrated -1.53 to $3.47 \mathrm{mV}$ of zeta potential. When compared with EUDRAGIT ${ }^{\circledR}$ nanoparticles found by Cetin et $\mathrm{al}^{20}$ the nanoparticles of the present study seem to show better stability for drug-carrier applications, since they showed stability to control their interactions with plasma proteins and bacterial membrane. This might be an indication that a zeta potential of $-7.16 \mathrm{mV}$, a little more negative than those observed by Cetin et $\mathrm{al}^{20}$ is related to a better stability of the nanoparticles.

\section{Encapsulation efficiency and in vitro release control}

Peptide encapsulation efficiency was evaluated by coupling FITC fluorophore to clavanin A. Released peptide evaluation was performed according to free peptide obtained after nanostructuration process by using spectrofluorimeter (FP 6500; JASCO) coupled to a Peltier temperature control system (JASCO). EUDRAGIT ${ }^{\circledR}$ nanostructures were capable of encapsulating $68.7 \%$ of clavanin A. Encapsulation efficiency could vary according to physicochemical characteristics, such as $\mathrm{pH}$, particle surface properties, nanostructuration methodology, and surfactant type. These characteristics interfere in chemical interactions between drugs and polymers, changing the encapsulation efficiency. ${ }^{18}$

Schaffazick and Guterres ${ }^{18}$ discuss efficiency rate for drug encapsulation, in a review where they showed different nanoparticles with $80 \%$ and $99 \%$ encapsulation efficiency. ${ }^{18}$ By using chitosan associated with antitumor peptide, Medeiros ${ }^{46}$ reported up to $80 \%$ encapsulation efficiency. Cetin et $\mathrm{al}^{20}$ showed $25 \%-62 \%$ of sodium diclofenac encapsulation using EUDRAGIT ${ }^{\circledR}$ associated with PLGA polymer and $56 \%, 69 \%$, and $81 \%$ cumulative release for

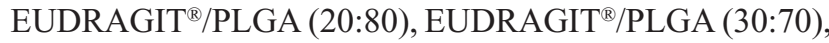
and EUDRAGIT ${ }^{\circledast} /$ PLGA (50:50), respectively, at 72 hours. Nassar et $\mathrm{al}^{28}$ obtained $88 \%$ of tacrolimus encapsulation efficiency using EUDRAGIT ${ }^{\circledR}$ nanoparticles developed with similar methodology to our study. ${ }^{28}$ These rates show that the encapsulation rate of clavanin A was increased by the use of methacrylate polymers, since $98 \%$ of peptide, besides the higher concentration of peptide, made it possible to obtain nanoparticles with low zeta potential and PDI, showing a higher stability.

After clavanin A nanostructuration, the samples presented $\mathrm{pH}$ 6.0. Aiming to observe nanostructure behavior at different $\mathrm{pHs}$, this parameter was adjusted for basic (above 7.0) and acidic (below 5.0). In both cases, polymer precipitation was observed, showing clear $\mathrm{pH}$ interference (data not shown). In general, $\mathrm{pH}$-sensitive structures have acidic or basic groups in the structure, which can react to small changes in environmental $\mathrm{pH} .{ }^{47}$ Methacrylate structures do indeed have an ammonium group on EUDRAGIT ${ }^{\circledR}$ RS 30 D, probably responsible for $\mathrm{pH}$ modification response. ${ }^{17,47}$ Moustafine et $\mathrm{al}^{37}$ showed that EUDRAGIT ${ }^{\circledR}$ polymers have $\mathrm{pH}$ dependence in an application on ibuprofen release. The authors demonstrated that in acidic medium ( $\mathrm{pH}$ 5.5), the polymer was completely ionized, which leads to an improvement in structure stability and also in slower drug release. Furthermore, by using basic medium ( $\mathrm{pH}$ 6.8), this same polymer has its carboxyl groups ionized, maintaining negative charges and further improving ibuprofen release. Yoo et $\mathrm{al}^{21}$ showed that EUDRAGIT $^{\circledR}$ S 100 nanoparticles containing two different compounds, sodium fluorescein and Nile red, showed a 
$\mathrm{pH}$-dependence behavior, being stable at acidic $\mathrm{pH}$. However, when $\mathrm{pH}$ was adjusted to neutral, the nanoparticles were unstable and drugs were quickly released. ${ }^{21}$

Release assays were performed by using $100 \mu \mathrm{g}$ of nanostructured clavanin A. Aiming to observe the time dependence of release, these structures were evaluated for 7 days. These assays showed significant peptide release for 7 days in water solution, with a major release $(69 \%)$ of encapsulated peptide occurring after 48 hours (Figure 2). Release time seems to be essential for evaluating aggregation and/or particle fusion associated with physicochemical properties. ${ }^{16,48}$ Using PLGA nanoparticles containing insulin, Wang et $\mathrm{al}^{49}$ also performed release assays with azide sodium solution at $\mathrm{pH} 7.4$ containing bovine serum albumin. After 7 days, almost half of the nanoencapsulated insulin was released. ${ }^{49}$ Furthermore, Cetin et al ${ }^{20}$ yielded

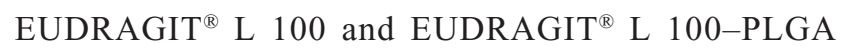
nanoparticles containing sodium diclofenac. In vitro drug release was studied at $\mathrm{pH}$ 6.8. After 4 hours, 38\% of the drug was released using EUDRAGIT ${ }^{\circledR}$ L 100 and 47\% by using EUDRAGIT ${ }^{\circledR}$ L 100-PLGA. Almost complete release (98\%) of sodium diclofenac in EUDRAGIT ${ }^{\circledR}$ L 100 particles was observed after 12 hours. Moreover, different release rates were observed in different polymer combinations such as EUDRAGIT ${ }^{\circledR} /$ PLGA $^{20: 80}$ (56\%), EUDRAGIT ${ }^{\circledR} /$ PLGA 30:70 (69\%), and EUDRAGIT ${ }^{\circledR} /$ PLGA 50:50 (98\%) nanoparticles, respectively. Release control can be influenced, firstly, by drug-polymer association, and afterwards by nanostructure behavior in suspension. ${ }^{50}$

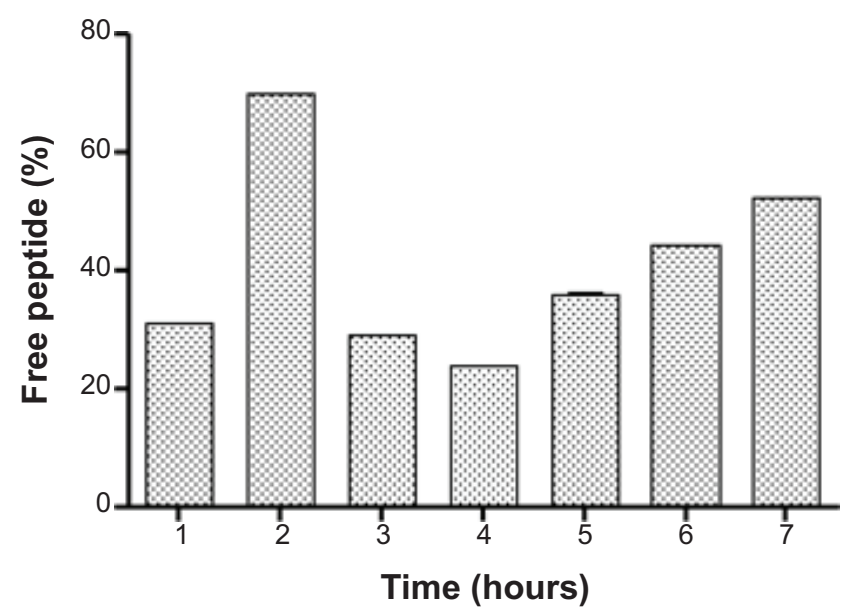

Figure 2 Peptide release assays were performed by using FITC marked Eudragit ${ }^{\circledR}$ nanoencapsulated clavanin.

Notes: Peptide concentration was calculated by using spectrofluorimeter (FP 6500; JASCO, Tokyo, Japan). Release was performed in distilled water at $\mathrm{pH} 6.0$ and temperature $37^{\circ} \mathrm{C}$. Released peptide concentration (Rp) was calculated using the standard concentration of free peptide (Fp) released after clavanin A encapsulation (Ep) according to experimental groups. In summary, Rp = Ep - Fp.
The release rate, both in vivo and in vitro, could be dependent on nanoparticle properties such as drug distribution on the surface and/or in the matrix of the particle, the polymer diffusion area, and also the processes of diffusion and erosion. Nevertheless, the in vitro assays can demonstrate the behavior of nanoparticles in a water environment, demonstrating cognate stability during storage. Moreover, the in vivo analyses showed peptide release in a physiologic environment. So these data suggest that in vivo and future experiments can provide nanoparticle pharmacokinetics and dynamics in physiologic solution.

\section{In vitro bioassays}

In vitro bioassays were performed against $E$. coli, $K$. pneumoniae, $S$. aureus, and $P$. aeruginosa. Obtained data showed that nanoparticles containing $12 \mu \mathrm{g}$ of peptide were able to inhibit $91 \%$ of $S$. aureus development. No antibiotic activities were obtained with free peptide at the same concentration or by using empty nanostructures. These same nanoparticles showed low deleterious activity toward K. pneumoniae (20\%) and P. aeruginosa (39.8\%), and $E$. coli was not affected. Turos et $\mathrm{al}^{14}$ showed polyacrylate nanoantibiotics associated with penicillin against methicillin-resistant $S$. aureus (MRSA), while, in this study, $64 \mu \mathrm{g} \cdot \mathrm{mL}^{-1}$ minimum inhibitory concentration was also observed against MRSA. ${ }^{14,15}$ Another study performed by Cheow et $\mathrm{al}^{38}$ showed levofloxacin-loaded polymeric nanoparticles with 0.03 and $0.15 \mu \mathrm{g} \cdot \mathrm{mL}^{-1}$ minimum inhibitory concentration and minimum biofilm inhibitory concentration against E. coli. ${ }^{38}$ Furthermore, no hemolytic activities for tested samples were observed (Figure S4), suggesting no cytotoxic activity against these cells, as previously observed by Nassar et al. ${ }^{28}$ These results demonstrated that nanoformulated clavanin here studied could be a suitable candidate for pharmaceutical applications. This experiment associated with survival assays displayed in Figure 3 allows peptide viability to be inferred.

Recent studies have demonstrated nanoantibiotic action against Gram-positive and -negative bacteria. Turos et $\mathrm{al}^{14}$ described polyacrylate nanoparticles covalently bound to penicillin prepared using an emulsion polymerization method in order to increase antibiotic solubility and improve antimicrobial activity against the MRSA. Moreover, Rai et $\mathrm{al}^{51}$ reported gold nanoparticles (22-25 $\mathrm{nm}$ diameter) containing the antibiotic cefaclor, which interferes in peptidoglycan layer synthesis, with enhanced activity toward $S$. aureus and E. coli. ${ }^{51}$ Cheow et $\mathrm{al}^{38}$ proposed the use of PLGA nanoparticles containing 
A

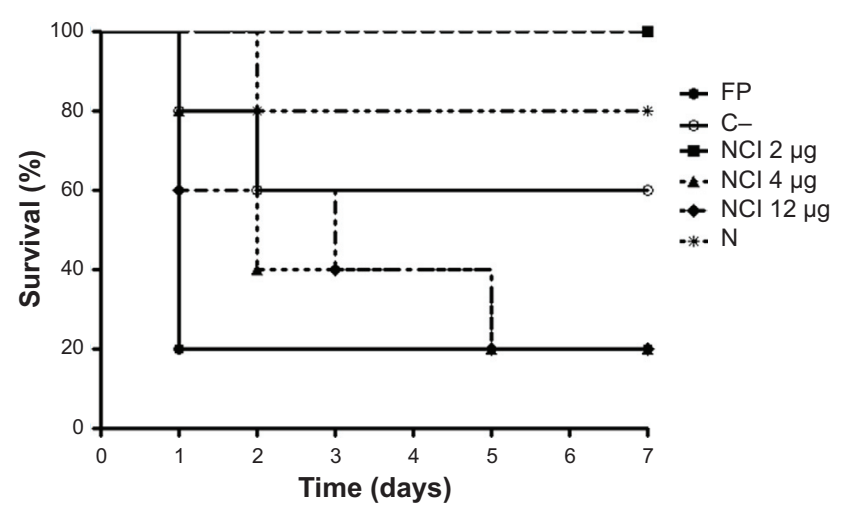

B

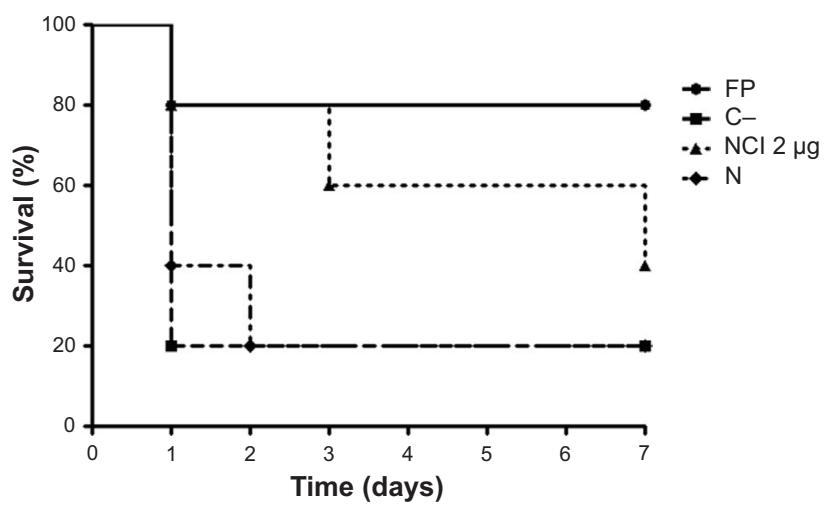

Figure 3 Survival rate analysis was performed after sub-lethal (A) and lethal (B) sepsis inductions.

Notes: Sepsis induction was performed by using a bacterial pool consisting of Staphylococcus aureus, Escherichia coli, Klebsiella pneumoniae, and Pseudomonas aeruginosa. The free peptide (FP) was compared with nanostructured clavanin $\mathrm{A}(\mathrm{NCl})$, and the free structure $(\mathrm{N})$, which does not contain the peptide. For sub-lethal bioassays, different concentrations of nanostructured clavanin A were used: 2,4 , and $12 \mu \mathrm{g}$; for lethal sepsis, only nanostructured clavanin $2 \mu \mathrm{g}$ was tested. Animals were monitored at regular intervals for up to 24 hours for 7 days. Results are expressed as the percentage of survival.

the antibiotic levofloxacin, with efficient activity against P. aeruginosa when compared with free levofloxacin. ${ }^{38}$ Another study using levofloxacin showed the successful use of poly( $\varepsilon$-caprolactone) nanoparticles against E. coli biofilm formation. ${ }^{52}$

\section{In vivo antibacterial analysis}

In vivo antibacterial evaluation was performed by survival rate in mice submitted to intraperitoneal sepsis induced by a polymicrobial pool injection. Challenges on the seventh day showed $100 \%$ survival for animals undergoing induced sub-lethal sepsis (Figure 3), using a bacterial mix containing S. aureus, K. pneumoniae, P. aeruginosa, and E. coli, and treated nanostructured clavanin A with $0.2 \mu \mathrm{g} \cdot \mathrm{kg}^{-1}$. Sublethal sepsis was tested for three different doses of nanostructured clavanin A $\left(2,4\right.$, and $\left.12 \mu \mathrm{g} \cdot \mathrm{mL}^{-1}\right)$. Aiming to evaluate only higher activity doses, lethal sepsis was tested only for nanostructured clavanin $2 \mu \mathrm{g} \cdot \mathrm{mL}^{-1}$. When nanoparticles containing clavanin A $1.2 \mu \mathrm{g} \cdot \mathrm{kg}^{-1}$ and $0.4 \mu \mathrm{g} \cdot \mathrm{kg}^{-1}$ were used, only $20 \%$ of survival was observed. Analysis using lethal induced sepsis (Figure 3 ) showed that $40 \%$ of animals treated with nanostructured peptide $\left(0.2 \mu \mathrm{g} \cdot \mathrm{kg}^{-1}\right)$ survived until the seventh day, and only $20 \%$ of animals treated with empty nanostructures survived until the seventh day. Free peptides did not show survival index in either case. Since no polymeric nanoparticles containing antimicrobial peptides have been evaluated against sepsis until now, only a few studies were found in the literature. Giacometti et a ${ }^{53}$ showed that intravenous doses of the antimicrobial peptides buforin II ( $\left.1 \mathrm{mg} \cdot \mathrm{kg}^{-1}\right)$, indolicidin $\left(1 \mathrm{mg} \cdot \mathrm{kg}^{-1}\right)$, and KFFKFFKFF sequence $\left(1 \mathrm{mg} \cdot \mathrm{kg}^{-1}\right)$ were able to increase mouse survival rates, showing $33 \%, 53 \%$, and $66 \%$ survival, respectively, against $20 \%$ survival rate presented by $20 \mathrm{mg} \cdot \mathrm{kg}^{-1}$ imipenem (positive control). Cirioni et al ${ }^{54}$ used magainin $\left(1 \mathrm{mg} \cdot \mathrm{kg}^{-1}\right)$, an antimicrobial peptide, against $E$. coli septic shock in rat model. In that study, the author showed $73.3 \%$ survival in comparison to $67 \%$ obtained by using $60 \mathrm{mg} \cdot \mathrm{kg}^{-1}$ of piperacillin, a beta-lactam antibiotic. In Giacometti et $\mathrm{al}^{53}$ and Cirioni et $\mathrm{a}^{54}$ free peptides were used to control sepsis infection, at peptide concentrations above $1 \mathrm{mg} \cdot \mathrm{kg}^{-1}$. Data here reported show the antibiotic activity against a bacterial mix containing $S$. aureus, K. pneumoniae, $P$. aeruginosa, and E. coli using $1.2 \mu \mathrm{g} \cdot \mathrm{kg}^{-1}$ of nanostructured clavanin A. In this context, our peptide showed better activity when nanostructured in EUDRAGIT ${ }^{\circledR}$ polymers.

Interactions between nanoparticles and bacterial membranes can improve the therapeutic drug effects, providing membrane disruption and leading to antimicrobial activity. ${ }^{20,23,55}$ Aiming to observe nanoparticle adhesion on bacterial membrane, Dillen et $\mathrm{a}^{23}$ discussed the strong interactions between nanoparticles (formed by EUDRAGIT ${ }^{\circledR}$ and PLGA + EUDRAGIT ${ }^{\circledR}$ ) and bacterial membranes of $S$. aureus and $P$. aeruginosa. The authors showed that the interaction between cationic nanoparticles formed by EUDRAGIT ${ }^{\circledR}$ probably provides an enhanced electrostatic interaction, making a better adhesion to microorganisms than anionic PLGA nanoparticles. ${ }^{23}$ Nanoparticles were here produced by using EUDRAGIT ${ }^{\circledR}$ L 100-55, an anionic polymer and EUDRAGIT ${ }^{\circledR}$ RS $30 \mathrm{D}$, a polymer with a quaternary ammonium group responsible for making polymer permeability. ${ }^{17,19}$ Immunomodulatory assays (Figure 4B and C) showed that nanostructures without 
A

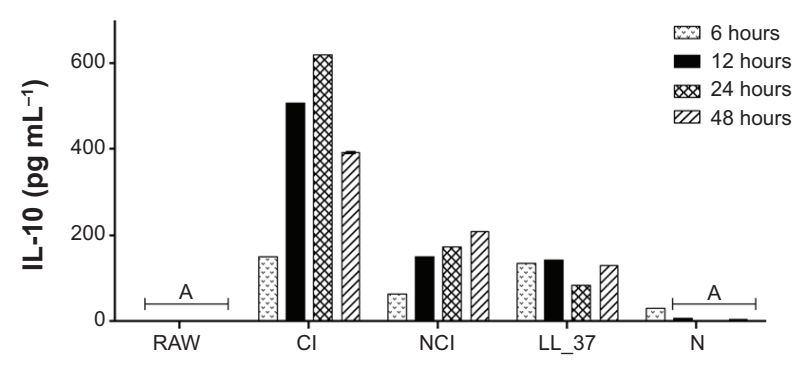

B

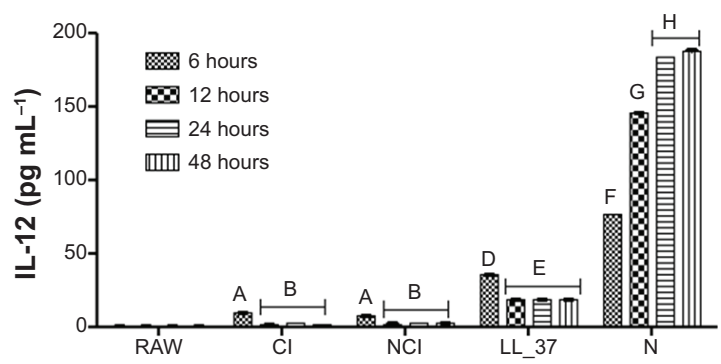

C

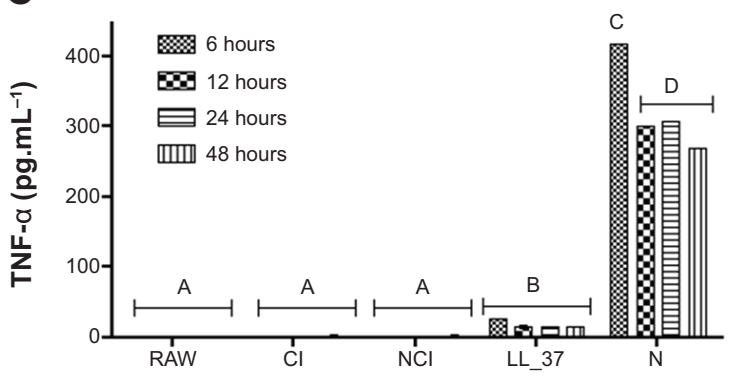

Figure 4 IL-I0 (A), IL-I2 (B), and TNF- $\alpha$ (C) dosage determined in the supernatant of RAW 264.7 cells.

Notes: Cells were stimulated with free peptide $(\mathrm{Cl})$, nanostructured peptide $(\mathrm{NCl}), 3 \mu \mathrm{M}$ immunomodulatory peptide (LL_37), and empty nanostructure ( $\mathrm{N}$ ) concentration analyzed after 6, 12, 24, and 48 hours of inflammatory process induction. Data represent the average concentration of $\mathrm{Cl}$, NCl, LL-37, and $\mathrm{N}$ at each time point of three experiments performed in triplicate, expressed as mean \pm standard deviation. Statistical analysis were performed using ANOVA follow by Bonferoni analysis. Different letters (A-H) correspond to values significantly different at $P$-value $>0.01$.

Abbreviations: IL, interleukin; TNF, tumor necrosis factor.

peptide showed a stimulation of IL-12 and TNF- $\alpha$ cytokines. Lee et $\mathrm{al}^{56}$ showed cytokines stimulation by thiolated EUDRAGIT $^{\circledR}$ microspheres used for vaccines containing F4 and F18 antigens isolated from E. coli. The authors observed cytokine stimulation even using thiolated EUDRAGIT ${ }^{\circledR}$ microspheres without the antigens. Furthermore, nanoparticles can provide a stimulation or suppression effect on the immune system, ${ }^{19,57}$ which is an important point in sepsis medicine, since they can provide a systemic inflammatory response syndrome (SIRS) control, avoiding septic shock. ${ }^{58}$

\section{Immunologic in vitro assays}

In order to observe whether nanostructured clavanin, in addition to antibacterial activities, is able to modulate the immune system, an immunomodulator effect analysis was performed using LL-37 as control, which is a peptide with ability to modulate inflammatory mediators by different cell types. ${ }^{59}$ For this, free clavanin, nanostructured clavanin, and nanostructures without clavanin were evaluated according to their effects on regulatory (IL-10) and pro-inflammatory (IL-12 and TNF- $\alpha$ ) cytokine synthesis by RAW 264.7 cells (Figure 4). All of them showed $100 \%$ increase in stimulation at IL-10 level when compared with negative control (untreated RAW 264.7 cells) at 6 hours. This production was reduced by $39 \%$ after 48 hours by free peptide. No significant reductions were observed for nanostructured clavanin and nanostructures (Figure 4). On the other hand, IL-12 was stimulated by $26 \%$ with free peptide treatment when compared with LL-37, while nanostructured clavanin stimulated IL-12 secretion by $28 \%$ when compared with LL-37, but after 48 hours stimulation fell 15\%. A similar data pattern was obtained for TNF- $\alpha$ level. Empty nanostructure caused higher TNF- $\alpha$ stimulation in comparison to LL-37, free peptide, and nanostructured peptide (Figure 4). These cytokines can be effective in immune system modulation in response to the excessive immune response caused by SIRS. As showed by Moreno et a ${ }^{58}$ IL- 12 cytokine is fundamental for an efficient host defense in polymicrobial sepsis, since it acts on IFN- $\gamma$ induction and stimulation of phagocytic and microbicidal activities of neutrophils.

In summary, nanostructured clavanin A showed 100\% IL-10, 28\% IL-12, and 8\% TNF- $\alpha$ stimulation (Figure 4). Nanostructures without peptide showed inflammatory activity, probably explained by the presence of polymer compound. EUDRAGIT ${ }^{\circledR}$ L $100-55$ and EUDRAGIT ${ }^{\circledR}$ RS 30 D are methacrylate polymers and can present inflammatory effects on the human system when at higher concentrations. ${ }^{22}$ Despite 
stimulation of IL-12, nanostructures associated with clavanin A showed a reduced stimulus when compared with nanostructures without peptide. During sepsis, the immune system response is completely activated, a super stimulation of immune system cells starts and results in cytokine imbalance. This leads to an inflammatory process, damaging the host system by excessive immune response. In this context, sepsis cases are aggravated by SIRS, but this overexpression can be decreased by use of immunomodulatory drugs associated with antibiotic medicine. ${ }^{22,60}$ Nanostructured clavanin $\mathrm{A}$ showed both immunomodulatory and antibiotic effects.

Zolnik et $\mathrm{al}^{57}$ revised the interaction of nanoparticles and immune system cells. These authors argue that the nanoparticles can interact with the immune system and present compatibility, influenced by the chemical surface of nanoparticles, ${ }^{61}$ causing immunostimulation or immunosuppression. ${ }^{57,61}$ In fact, nanostructures can provide some antimicrobial activity against lower concentrations of bacteria by polymer-bacterial membrane interactions ${ }^{21,30}$ or induce immune response activity in the host system. ${ }^{57}$ However, these nanostructures were not able to provide antimicrobial activity at higher bacterial concentrations, as shown in in-vivo analysis, and cannot show effective modulation activity in response to the excessive immune response caused by SIRS. ${ }^{58,61}$ In general, nanostructures can stimulate or suppress the immune system and show a positive or negative response according to the applications of these structures. ${ }^{62}$ Some studies discussed immune system stimulation by methacrylate nanoparticles. ${ }^{20,62-66}$ Although IL-12 stimulation by nanostructures without peptide has been observed (Figure 4), this same stimulus was not observed when nanostructures were associated with clavanin, probably because clavanin A suppresses the effect as shown in Figure 4. Furthermore, it is important to report that besides IL-12 stimulation by nanostructures without peptide, no cytotoxic effects against erythrocytes were observed. The use of EUDRAGIT ${ }^{\circledR}$ polymers against inflammatory diseases was also reported by Coco et $\mathrm{al}^{63}$ who showed three different nanoparticles using EUDRAGIT ${ }^{\circledR}$ S 100 for the ovalbumin (drug model) delivery system against colon inflammatory bowel disease. Moreover, ibuprofen encapsulated with EUDRAGIT ${ }^{\circledR} \mathrm{R}$ 100 was evaluated for its ocular anti-inflammatory effects, showing increased ibuprofen dispersion and higher antiinflammatory activity. ${ }^{26}$

\section{Conclusion}

The data reported here showed an increase in clavanin A antimicrobial and immunomodulatory activity when the peptide was presented in a nanoparticle formulation, providing a promising drug against polymicrobial sepsis infection caused by $S$. aureus, E. coli, P. aeruginosa, and/or K. pneumoniae. Methacrylate nanoparticles can provide protection, specificity and controlled release of the peptide clavanin A. The obtained nanoparticles presented morphological characteristics that are viable for injectable drug application, ${ }^{44,67,68}$ since they did not show cytotoxic effect and small size; however, further experiments are needed to evaluate the use of methacrylate nanoparticles for this purpose. ${ }^{68}$ These properties demonstrated that the methods employed here in the nanoencapsulation of clavanin A have the potential for antibiotic drug design, and may be a promising technology for development of drugs and biotechnological products. For sepsis infection, the use of nanometric structures can provide low toxicity, better distribution, and extended treatment, avoiding interruptions in treatment. ${ }^{4,12,68}$

\section{Acknowledgment}

This work was supported by Conselho Nacional de Pesquisa e Desenvolvimento, Coordenação de Aperfeiçoamento de Pessoal de Nível Superior, Fundaçãode Apoio aPesquisadoDistrito Federal and Universidade Católoca de Brasília.

\section{Disclosure}

The authors report no conflicts of interest in this work.

\section{References}

1. Pittet D, Allegranzi B, Storr J, et al. Infection control as a major World Health Organization priority for developing countries. J Hosp Infect. 2008;68(4):285-292

2. Carvalhares TT, Pesquero MA, Quintana RC, et al. Identificação de Bactérias Causadoras de Infecção Hospitalar e Avaliação da Tolerância a Antibióticos. News Lab. 2008;86:106-114. Portuguese.

3. Medicine ACoCPSoCC. Consensus Conference: definitions for sepse and organ failure and guidelines for the use of innovative therapies in sepse. In: ACCP/SCCM, editor. Consensus Conference on Sepsis and Organ Failure. 1992;101(6):1644-1655.

4. Carvalho RH, Vieira JF, Filho PPG, Ribas RM. [Sepsis, severe sepsis and septic shock: clinical, epidemiological and prognostic characteristics of patients in an intensive care unit in a university hospital]. Rev Soc Bras Med Trop. 2010;43(5):591-593. Portuguese.

5. Lee IH, Zhao C, Cho Y, Harwig SS, Cooper EL, Lehrer RI. Clavanins, alpha-helical antimicrobial peptides from tunicate hemocytes. FEBS Letters. 1997;400(2):158-162.

6. Kindrachuk J, Nijnik A, Hancock REW. Host defense peptides: bridging antimicrobial and immunomodulatory activities. In: Comprehensive Natural Products II Chemistry and Biology. Oxford: Elsevier; 2010;5:175-216.

7. Zanetti-Ramos BG, Creczynski-Pasa TB. O desenvolvimento da nanotecnologia: cenário mundial e nacional de investimentos. [Nanotechnology development: world-wide and national investments]. Revista Brasileira de Ciências Farmacêuticas. 2008;89(2):95-101. Portuguese.

8. Galati R, Verdina A, Falasca G, Chersi A. Increased resistance of peptides to serum proteases by modification of their amino groups Z Naturforsch C. 2003;58(7-8):558-561 
9. Pini A, Giuliani A, Falciani C, et al. Antimicrobial activity of novel dendrimeric peptides obtained by phage display selection and rational modification. Antimicrob Agents Chemother. 2005;49(7): 2665-2672.

10. Gentilucci L, De Marco R, Cerisoli L. Chemical modifications designed to improve peptide stability: incorporation of non-natural amino acids, pseudo-peptide bonds, and cyclization. Curr Pharm Des. 2010;16(28):3185-3203.

11. Almeida JP, Chen AL, Foster A, Drezek R. In vivo biodistribution of nanoparticles. Nanomedicine (Lond). 2011;6(5):815-835.

12. Suri SS, Fenniri H, Singh B. Nanotechnology-based drug delivery systems. J Occup Med Toxicol. 2007;2:16.

13. Kreyling WG, Hirn S, Schleh C. Nanoparticles in the lung. Nat Biotechnol. 2010;28(12):1275-1276.

14. Turos E, Reddy GS, Greenhalgh K, et al. Penicillin-bound polyacrylate nanoparticles: restoring the activity of beta-lactam antibiotics against MRSA. Bioorg Med Chem Lett. 2007;17(12):3468-3472.

15. Turos E, Shim JY, Wang Y, et al. Antibiotic-conjugated polyacrylate nanoparticles: new opportunities for development of anti-MRSA agents. Bioorg Med Chem Lett. 2007;17(1):53-56.

16. Pinto Reis C, Neufeld RJ, Ribeiro AJ, Veiga F. Nanoencapsulation I. Methods for preparation of drug-loaded polymeric nanoparticles. Nanomedicine. 2006;2(1):8-21.

17. Evonik $^{\circledR}$. Specifications and test methods for EUDRAGIT ${ }^{\circledR}$ RL 30 D and EUDRAGIT ${ }^{\circledR}$ RS 30 D. Röhm GmbH \& Co KG; 2004.

18. Schaffazick SR, Guterres SS. Caracterização e estabilidade físicoquímica de sistemas poliméricos nanoparticulados para administração de fármacos. [Physicochemical characterization and stability of the polymeric nanoparticle systems for drug administration]. Química Nova. 2003;26(5):726-737. Portuguese.

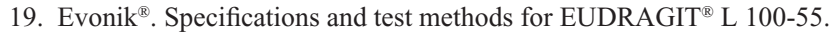
Röhm GmbH \& Co KG; 2004.

20. Cetin M, Atila A, Kadioglu Y. Formulation and in vitro characterization of Eudragit ${ }^{\circledR}$ L100 and Eudragit ${ }^{\circledR}$ L100-PLGA nanoparticles containing diclofenac sodium. AAPS Pharm Sci Tech. 2010;11(3):1250-1256.

21. Yoo JW, Giri N, Lee CH. pH-sensitive Eudragit nanoparticles for mucosal drug delivery. Int J Pharm. 2011;403(1-2):262-267.

22. Capparelli R, De Chiara F, Nocerino N, et al. New perspectives for natural antimicrobial peptides: application as antinflammatory drugs in a murine model. BMC Immunol. 2012;13:61.

23. Dillen K, Bridts C, Van der Veken P, et al. Adhesion of PLGA or Eudragit/PLGA nanoparticles to Staphylococcus and Pseudomonas. Int J Pharm. 2008;349(1-2):234-240.

24. Bi L, Yang L, Bhunia AK, Yao Y. Carbohydrate nanoparticle-mediated colloidal assembly for prolonged efficacy of bacteriocin against food pathogen. Biotechnol Bioeng. 2011;108(7):1529-1536.

25. Liu L, Xu K, Wang H, et al. Self-assembled cationic peptide nanoparticles as an efficient antimicrobial agent. Nat Nanotechnol. 2009;4: $457-463$.

26. Hirata IY, Cezari MHS, Nakate CR, et al. Internally quenched fluorogenic protease substrates: solid phase synthesis and fluorescence spectroscopy of peptides containing ortho-amino benzoyl/dinitrophenyl groups as donor-acceptor pairs. Letters in Peptide Science. 1995;1(6): 299-308.

27. Murphy JB, Kies MW. Note on spectrophotometric determination of proteins in dilute solution. Biochim Biophys Acta. 1960;45: 382-384.

28. Nassar T, Rom A, Nyska A, Benita S. Novel double coated nanocapsules for intestinal delivery and enhanced oral bioavailability of tacrolimus, a P-gp substrate drug. J Control Release. 2009;133(1):77-84.

29. Chicea D. Nanoparticles and nanoparticle aggregates sizing by DLS and AFM. J Optoelectronics Adv Mater. 2010;4(9):1310-1315.

30. Scalf J, West P. Part I: Introduction to Nanoparticle Characterization with AFM. 2006. Available from: http://www.nanoparticles.org/pdf/ Scalf-West.pdf. Accessed September 5, 2014.

31. Sheng LC, Qing LY, Mao LJ. The synthesis and properties studying of 1-D TaS2 nanostructure. Key Eng Mater. 2007:353-358.
32. NCCLS NCfCLS. Methods for Dilution Antimicrobial Susceptibility Tests for Bacteria That Grow Aerobically; NCCLS document M7-A6; 2003. p. 19087-1898.

33. Moreno SE, Alves-Filho JC, Rios-Santos F, et al. Signaling via platelet-activating factor receptors accounts for the impairment of neutrophil migration in polymicrobial sepsis. J Immunol. 2006;177(2): 1264-1271.

34. Sulkin ES, Willett JC. A Triple sugar-ferrous sulphate medium for use in identification of enteric organisms. J Lab Clin Med. 1940;25:649.

35. Kaplan EL, Meier P. Nonparametric estimation from incomplete observations. J Am Stat Assoc. 1958;53(282):457-481.

36. Lopez-Abarrategui C, Alba A, Silva ON, et al. Functional characterization of a synthetic hydrophilic antifungal peptide derived from the marine snail Cenchritis muricatus. Biochimie. 2012;94(4):968-974.

37. Moustafine RI, Zaharov IM, Kemenova VA. Physicochemical characterization and drug release properties of Eudragit E PO/Eudragit L 100-55 interpolyelectrolyte complexes. Eur J Pharm Biopharm. 2006;63(1):26-36.

38. Cheow WS, Chang MW, Hadinoto K. Antibacterial efficacy of inhalable levofloxacin-loaded polymeric nanoparticles against E. coli biofilm cells: the effect of antibiotic release profile. Pharm Res. 2010;27(8):1597-1609.

39. Fontana G, Licciardi M, Mansueto S, Schillaci D, Giammona G. Amoxicillin-loaded polyethylcyanoacrylate nanoparticles: influence of PEG coating on the particle size, drug release rate and phagocytic uptake. Biomaterials. 2001;22(21):2857-2865.

40. Chavan D, Andres D, Iannuzzi D. Note: ferrule-top atomic force microscope. II. Imaging in tapping mode and at low temperature. Rev Sci Instrum. 2011;82(4):046107.

41. Malvern. Dynamic light scattering: an introduction in 30 minutes. In: Malvern, editor. DLS technical note. Technical note (MRK656-01) ed; 2010

42. Wu J, Mao Y, Xu J, et al. Synthesis and characterization of gold nanoparticles based on low generational triethylene glycol-polyamidoamine dendrimers. J Nanosci Nanotechnol. 2010;10(3):2181-2184.

43. Nidhin M, Indumathy R, Sreeram KJ, Uni Nai B. Synthesis of iron oxide nanoparticles of narrow size distribution on polysaccharide templates. Bull Mater Sci. 2008;31(1):93-96.

44. ASTM ASfTaM. Zeta Potential of Colloids in Water and Waste Water. ASTM Standard. 1985:4187-4182.

45. Salvador-Morales C, Zhang L, Langer R, Farokhzad OC. Immunocompatibility properties of lipid-polymer hybrid nanoparticles with heterogeneous surface functional groups. Biomaterials. 2009;30(12):2231-2240.

46. Medeiros KA. Desenvolvimento e testes in vitro de nanopartículas de quitosana para liberação controlada de peptídeos antitumorais [Development and in vitro testing of chitosan nanoparticles for controlled release of anticancer peptides]. 2011. Portuguese.

47. Aguilar MR, Elvira C, Gallardo A, Vázquez B, Román JS. Smart polymers and their applications as biomaterials. In: Ashammakhi N, Reis R, Chiellini E, editors. Topics in Tissue Engineering. 2007.

48. Abdelwahed W, Degobert G, Stainmesse S, Fessi H. Freeze-drying of nanoparticles: formulation, process and storage considerations. $A d v$ Drug Deliv Rev. 2006;58(15):1688-1713.

49. Wang F, Chen Y, Benson HAE. Formulation of nano and micro PLGA particles of the model peptide insulin: preparation, characterization, stability and deposition in human skin. Open Drug Deliv J. 2008;2:1-9.

50. Soppimath KS, Aminabhavi TM, Kulkarni AR, Rudzinski WE. Biodegradable polymeric nanoparticles as drug delivery devices. J Control Release. 2001;70:1-20.

51. Rai A, Prabhune A, Perry CC. Antibiotic mediated synthesis of gold nanoparticles with potent antimicrobial activity and their application in antimicrobial coatings. J Mater Chem. 2010;20:6789-6798.

52. Kho K, Cheow WS, Lie RH, Hadinoto K. Aqueous re-dispersibility of spray-dried antibiotic-loaded polycaprolactone nanoparticle aggregates for inhaled anti-biofilm therapy. Powder Technol. 2010;203: $432-439$. 
53. Giacometti A, Cirioni O, Ghiselli R, et al. Potential therapeutic role of cationic peptides in three experimental models of septic shock. Antimicrob Agents Chemother. 2002;46(7):2132-2136.

54. Cirioni O, Giacometti A, Ghiselli R, et al. Single-dose intraperitoneal magainins improve survival in a gram-negative-pathogen septic shock rat model. Antimicrob Agents Chemother. 2002;46(1):101-104.

55. Helander IM, Alakomi H-L, Latva-Kala K, Koski P. Polyethyleneimine is an effective permeabilizer of Gram-negative bacteria. Mycrobiology. 1997;(143):3193-3199.

56. Lee WJ, Cha S, Shin M, Islam MA, Cho CS, Yoo HS. Induction of Th1 polarized immune responses by thiolated Eudragit-coated F4 and F18 fimbriae of enterotoxigenic Escherichia coli. Eur J Pharm Biopharm. 2011;79(2):226-231.

57. Zolnik BS, Gonzalez-Fernandez A, Sadrieh N, Dobrovolskaia MA Minireview: nanoparticles and the immune system. Endocrinology. 2010;151(2):458-465.

58. Moreno SE, Alves-Filho JC, Alfaya TM, da Silva JS, Ferreira SH, Liew FY. IL-12, but not IL-18, is critical to neutrophil activation and resistance to polymicrobial sepsis induced by cecal ligation and puncture. J Immunol. 2006;177(5):3218-3224.

59. Abbas AK, Lichtman AH. Basic Immunology; Philadelphia, PA, USA. Saunders/Elsevier; 2009.

60. de Medeiros Brito, Maria de Fátima. Síndrome da resposta inflamatória sistêmica: denominação possivelmente aplicável a fenômenos dermatológicos [Systemic inflammatory response syndrome: a denomination possibly applied to dermatological phenomena]. An Bras Dermatol. 2007;82(3):359-361.
61. Dobrovolskaia MA, McNeil SE. Immunological properties of engineered nanomaterials. Nat Nanotechnol. 2007;2(8):469-478.

62. Svenson S, Prud'homme RK. Multifunctional Nanoparticles for Drug Delivery Applications: Imaging, Targeting, and Delivery; Arlington, MA, USA. Springer; 2012.

63. Coco R, Plapied L, Pourcelle V, et al. Drug delivery to inflamed colon by nanoparticles: comparison of different strategies. Int J Pharm. 2013;440(1):3-12.

64. Bucolo C, Maltese A, Puglisi G, Pignatello R. Enhanced ocular antiinflammatory activity of ibuprofen carried by an Eudragit RS100 nanoparticle suspension. Ophthalmic Res. 2002;34(5):319-323.

65. Gardner AB, Lee SK, Woods EC, Acharya AP. Biomaterials-based modulation of the immune system. Biomed Res Int. 2013;2013:732182.

66. Naahidi S, Jafari M, Edalat F, Raymond K, Khademhosseini A, Chen P. Biocompatibility of engineered nanoparticles for drug delivery. J Control Release. 2013;166(2):182-194.

67. Villanova JCO, Oréfice RL, Cunha AS. Aplicações Farmacêuticas de Polímeros [Pharmaceutical applications of polymers]. Polímeros. 2010;20(1):51-64. Portuguese.

68. Gref R, Minamitake Y, Langer RS, inventors; Massachusetts Institute Of Technology, assignee. Biodegradable injectable nanoparticles. United States patent US5543158 A. 1996 Aug 6. 


\section{Supplementary materials}

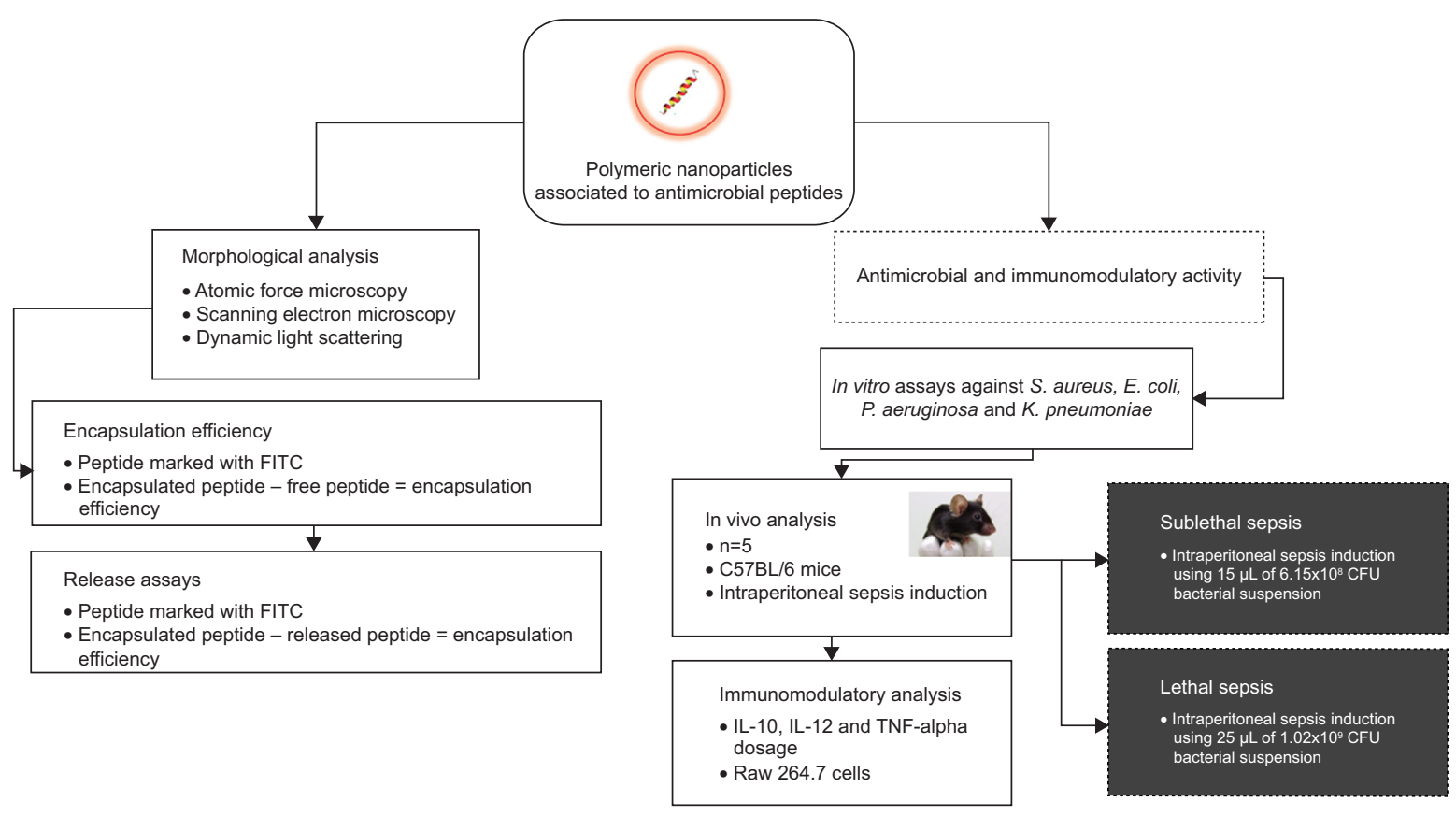

Figure SI Workflow for clavanin A nonoencapsulation and further morphological and functional characterization. Abbreviations: FITC, fluorescein isothiocyanate; IL, interleukin; TNF, tumor necrosis factor.

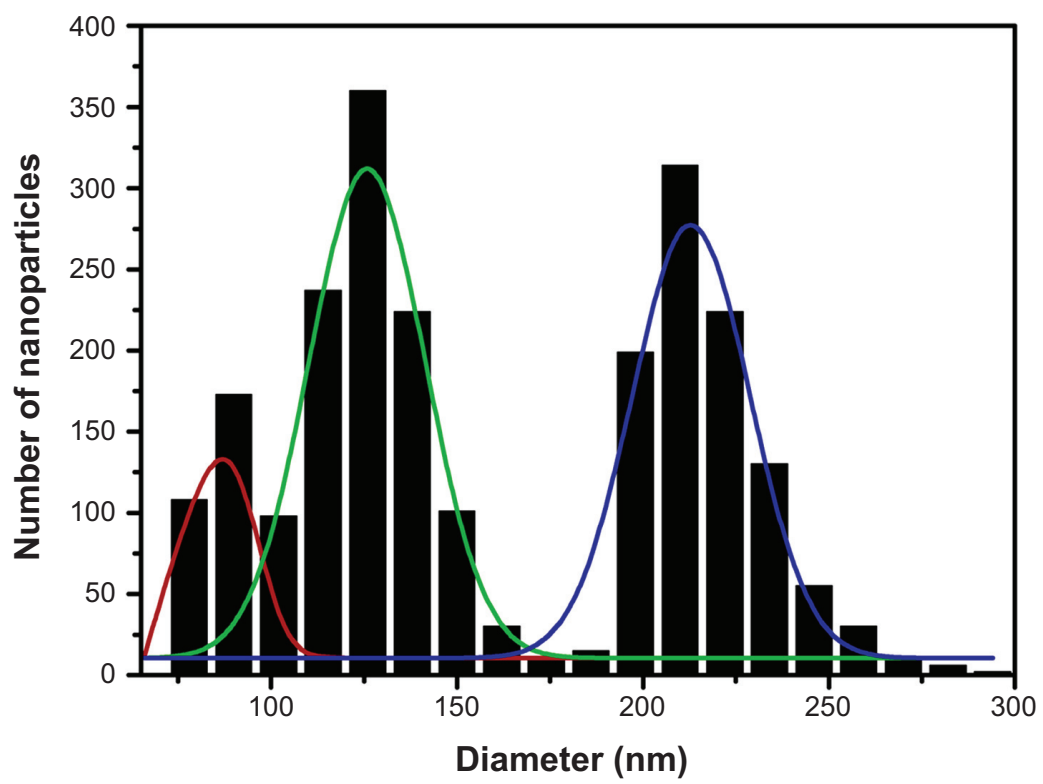

Figure S2 Atomic force microscopy analysis of methacrylate nanoparticles for particles obtained using 3:I (w:w) of polymer (Eudragit ${ }^{\circledR}$ LI00-55) and copolymer (Eudragit ${ }^{\circledR}$ RS30D), showing trimodal Gaussian distribution for diameter (69 and $260 \mathrm{~nm}$ ), with majority showing $120 \mathrm{~nm}$. 
A

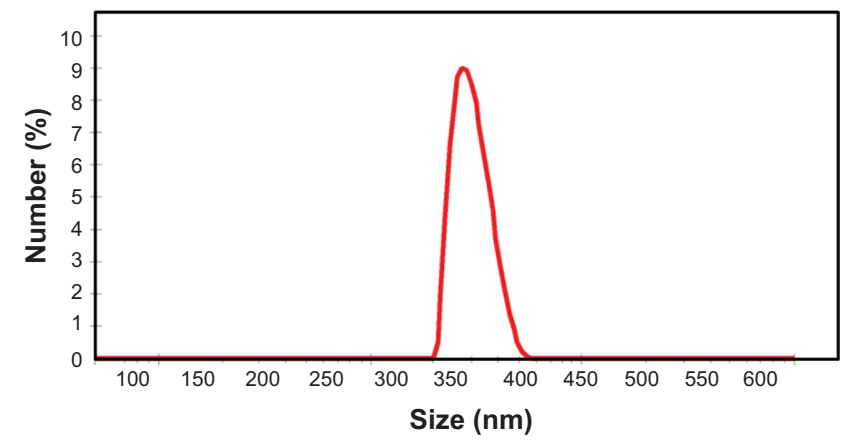

B

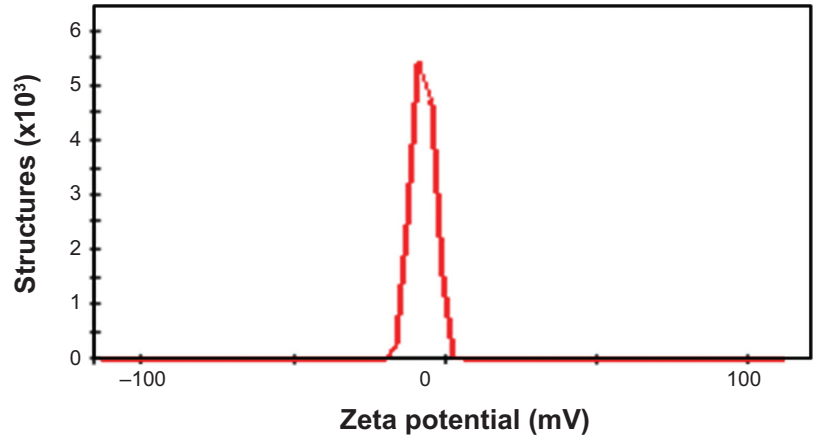

Figure S3 Dynamic light scattering analysis of methacrylate nanoparticles was obtained by use of 3:I ratios of polymer (Eudragit ${ }^{\circledR}$ LI00-55) and copolymer (Eudragit ${ }^{\circledR}$ RS30D). (A) A unimodal Gaussian distribution showing nanoparticles of approximately $372 \mathrm{~nm}$. (B) Experiment showing nanoparticles with -7.16 mV zeta potential.

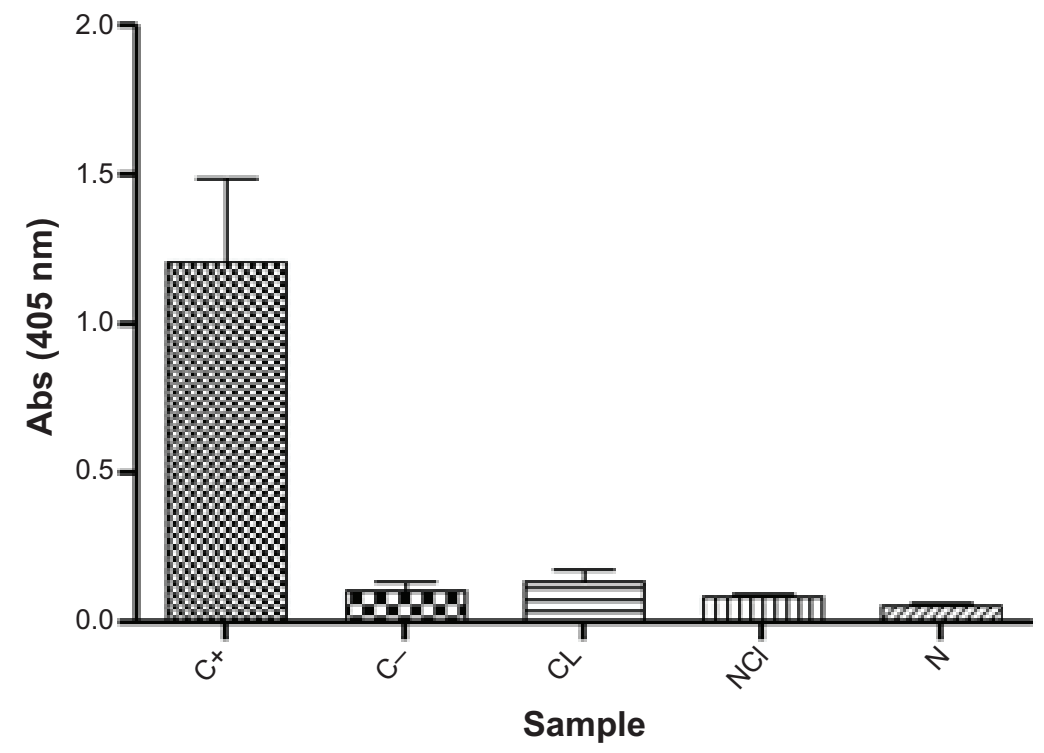

Figure S4 Hemolytic activity analysis.

Notes: Free peptide $(\mathrm{Cl})$ was compared with nanostructures clavanin $\mathrm{A}(\mathrm{NCl})$ and free structure $(\mathrm{N})$, which does not contain the peptide. For bioassays $12 \mu \mathrm{g}$ of nanostructured peptide was used. C+ correspond to positive control by using $100 \%$ Triton X-100. C-correspond to negative control that was saline solution.

Abbreviation: Abs, absorbance.

\section{Publish your work in this journal}

The International Journal of Nanomedicine is an international, peerreviewed journal focusing on the application of nanotechnology in diagnostics, therapeutics, and drug delivery systems throughout the biomedical field. This journal is indexed on PubMed Central, MedLine, CAS, SciSearch $®$, Current Contents $\AA /$ Clinical Medicine,
Journal Citation Reports/Science Edition, EMBase, Scopus and the Elsevier Bibliographic databases. The manuscript management system is completely online and includes a very quick and fair peer-review system, which is all easy to use. Visit http://www.dovepress.com/ testimonials.php to read real quotes from published authors.

\footnotetext{
Submit your manuscript here: http://www.dovepress.com/international-journal-of-nanomedicine-journal
} 